\title{
Upaya Perlindungan Hukum Terhadap Anak Selaku Korban Kejahatan Asusila dalam Perdagangan Anak
}

\author{
Priegel Manggolokusumo1, Yeni Widowaty ${ }^{2}$ \\ 1,2 Fakultas Hukum, Universitas Muhammadiyah Yogyakarta \\ Email : ${ }^{1}$ priegel.manggolokusumo.2012@law.umy.ac.id \\ 2yeniwidowaty@umy.ac.id
}

Info Artikel

\section{Kata Kunci :}

eksploitasi seksual, komersial anak, perlindungan hukum

\section{Perjalanan Artikel :}

Diterima : 27 Juli 2020

Direview : 27 Agustus 2020

Direvisi : 29 Agustus 2020

Dipublikasikan : Agustus 2020

DOI: 10.18196/ijclc.v1i2.9648

\begin{abstract}
Abstrak
Eksploitasi Seksual Komersial Anak (ESKA) dalam tindak pidana perdagangan anak sampai saat ini sering terjadi dan mengkhawatirkan anak sebagai penerus masa depan bangsa. Jenis penelitian ini adalah penelitian dengan metode analitis normatif yang mencakup penelitian terhadap asas-asas, sistematika, taraf sinkronisasi, sejarah dan perbandingan hukum. Data yang digunakan dalam penelitian ini adalah data sekunder yang terdiri dari bahan hukum primer, bahan hukum sekunder dan bahan hukum tersier. Berdasarkan hasil analitis yang telah dilakukan untuk mengetahui bentuk-bentuk perlindungan terhadap anak yang menjadi korban kejahatan asusila dalam perdagangan anak, bentuk perlindungan hukum terbagi menjadi dua yaitu; bantuan langsung (Concreto) dan bantuan tidak langsung (Abstracto). Bentuk Concreto yaitu dengan memberikan bantuan hukum, perlindungan, pendampingan serta mengupayakan perolehan kompensasi, sedangkan bantuan Abstracto yaitu dengan penerapan norma-norma dan peraturan hukum terhadap anak sesuai peraturan perundang-undangan secara berkala.
\end{abstract}

\section{Pendahuluan}

Indonesia merupakan negara hukum sebagaimana diatur dalam Pasal 1 ayat (3) UndangUndang Dasar 1945. Hukum dirumuskan untuk mengatur dan melindungi segala kepentingan masyarakat agar tidak terjadi benturan serta untuk menjunjung tinggi hak asasi manusia. Secara internasional, perlindungan terhadap anak diatur dalam Konvensi Hak Anak PBB tahun 1989 yang kemudian diratifikasi pemerintah Indonesia melalui Keputusan Presiden Nomor 36 tahun 1990. Setelah meratifikasi Konvensi Hak, Indonesia kemudian meratifikasi Konvensi International Labour Organization (Organisasi Perburuhan Internasional selanjutnya disingkat ILO) Nomor 138 dan 182 yang intinya berupaya mencegah kemungkinan anak terjerumus pada eksploitasi dunia kerja yang berlawanan dengan Konvensi Hak Anak serta kelangsungan hidupnya. Dengan demikian Indonesia mengesahkan Undang-Undang Nomor 35 Tahun 2014 tentang Perubahan Atas Undang-Undang Nomor 23 Tahun 2002 tentang Perlindungan Anak.

Anak adalah amanah sekaligus karunia Tuhan Yang Maha Esa yang senantiasa harus di jaga dan merupakan bagian dari generasi muda penerus cita-cita perjuangan bangsa. Anak-anak memerlukan pembinaan dan perlindungan dalam rangka menjamin pertumbuhan dan perkembangan fisik, mental dan sosial secara utuh, serasi, selaras dan seimbang. ${ }^{1}$ Kejahatan terhadap anak saat ini semakin mengkhawatirkan, pasalnya kasus-kasus kejahatan prostitusi yang menjadikan anak sebagai pekerja seks komersial semakin sering diberitakan di media informasi. Kasus pada awal bulan Oktober 2016, yaitu terbongkarnya prostitusi anak di kota Bogor dengan

\footnotetext{
${ }^{1}$ Mohammad Taufik Makaro, 2013, Hukum Perlindungan Anak dan Penghapusan Kekerasan Dalam Rumah Tangga,Jakarta, Rineka Cipta, hlm. 1
} 
jumlah anak yang diperdagangkan oleh pelaku diperkirakan lebih dari 100 orang dan 27 di antaranya berusia 13-17 tahun. ${ }^{2}$

Eksploitasi Seksual Komersial Anak (ESKA) adalah pelecehan seksual terhadap anak di bawah umur demi keuntungan ekonomi. Eksploitasi ini melibatkan pelecehan fisik, pornografi, pelacuran, dan penyelundupan anak-anak untuk tujuan yang melanggar hukum. Jumlah kasus ESKA yang diketahui terus meningkat dan Anak-anak diculik serta dijual menjadi pekerja paksa di industri seks ilegal. Beberapa keluarga miskin menjual anak-anak mereka kepada pedagang dengan harapan memberi anak-anak kehidupan yang lebih baik. Ada laporan yang terdokumentasi tentang anakanak yang ditahan di ruang bawah tanah dan kondisi seperti budak lainnya di mana mereka dipukuli, kurang gizi, diancam, dan dieksploitasi secara seksual. Anak-anak yang seharusnya menikmati masa kecil untuk bermain dan tumbuh bersama dengan anak seusianya menjadi sangat riskan menjadi korban kejahatan bagi orang dewasa di sekitar mereka.

Bentuk-bentuk ESKA yang utama dijumpai adalah pelacuran dan perdagangan anak untuk tujuan seksual. Berdasarkan pencatatan tahun 2017, diketahui bahwa 404 korban anak mayoritas merupakan perempuan yang berjumlah 223 anak dan disusul oleh anak laki-laki dengan jumlah 117 anak. Anak sebagai korban terbanyak pada kejahatan perdagangan anak untuk seksual dengan jumlah korban sebanyak 183 anak, selanjutnya kejahatan seksual perdagangan anak sebanyak 74 korban, lalu pornografi anak sebanyak 44 korban, prostitusi anak sebanyak 40 korban, dan di urutan terakhir adalah kasus seks anak di tempat pariwisata dengan total korban 2 orang anak. ${ }^{3}$ Pada tahun 2004 di Indonesia tercatat 40.000-70.000 anak telah menjadi korban ESKA. Lebih rincinya di Semarang, Yogyakarta dan Surabaya terdapat 3.408 anak korban pelacuran baik di lokalisasi, jalanan, tempat-tempat hiburan, dan panti pijat. ${ }^{4}$

Yogyakarta memiliki kasus eksploitasi seksual yang melibatkan anak-anak di bawah umur dan banyak terjadi di pesisir selatan pantai Bantul serta beberapa kasus di Yogyakarta kota, Sleman dan Gunung Kidul. Menyadur data dari Komisi Perlindungan Anak Indonesia (KPAI) pada tahun 2010 hingga 2012, ada peningkatan yang mencengangkan terkait kasus anak. Pada 2010 tercatat ada 410 kasus dan meningkat menjadi 480 pada tahun 2011. Tahun 2012 meningkat menjadi 673 kasus, bahkan menurut catatan ECPAT (End Child Prostitution, Child Pornography and Trafficking of Children) Indonesia pada penelitian tahun 2013 bahwa 150.000 anak menjadi korban perdagangan untuk tujuan seksual. ${ }^{5}$ Jika mengacu pada Konvensi Hak Anak dan Konvensi ILO, maka yang disebut pekerja anak adalah para pekerja yang berusia di bawah 18 tahun. ILO menunjukkan masih ada 1,5 juta $(4,3 \%)$ pekerja anak di Indonesia pada 2010 dan setengah dari pekerja anak 5-17 tahun diperkirakan melakukan pekerjaan disektor berbahaya yang dapat mengganggu kesehatan, keselamatan, serta perkembangan moral. ${ }^{6}$

Eksploitasi seksual komersial anak merupakan tindak kejahatan asusila yang secara berat telah melanggar hak asasi manusia terutama hak-hak hidup pada anak. Termuat tiga bentuk utama eksploitasi secara seksual komersial terhadap anak, yaitu pornografi anak, pelacuran anak dan perdagangan (trafficking) anak untuk tujuan seksual, ditambah dengan wisata seks anak dan perkawinan anak (pernikahan dini) yang menjadikan lima bentuk ESKA. ${ }^{7}$ Besarnya harapan dan beban yang diberikan kepada anak sebagai penopang bangsa di masa depan maka sepantasnya

\footnotetext{
${ }^{2}$ Marsaha Habib, Prostitusi Anak: Jangan Salah Fokus, 18 Oktober 2016, https://medium.com/@puskapa/prostitusi-anak-jangan-salah-fokus-16393be09e8f

${ }^{3}$ Iman Rahdana, 2018, Catatan Tahun 2017: 404 Anak Menjadi Korban ESKA, https://ecpatindonesia.org/berita/catatan-ecpat-indonesia-tahun-2017-404-anak-menjadi-korban-eska/, diakses 15 Januari 2018.

${ }^{4}$ Ahmad Sofian, 2008, Eksploitasi Seksual Komersial Anak di Indonesia, Medan, Koalisi Nasional Penghapusan Eksploitasi Seksual Komersial Anak, hlm.7.

${ }^{5}$ Muh Syaifullah, 2016, Pelacuran Anak Marak, Pemerintah Didesak Bertindak, https://nasional.tempo.co/read/791363/pelacuran-anak-marak-pemerintah-didesak-bertindak/full\&view=ok.

${ }^{6}$ Kementerian Ketenagakerjaan RI, 2014, Peta Jalan (Roadmap) Menuju Indonesia Bebas Pekerja Anak Tahun 2022, Jakarta, hlm.8.

${ }_{7}$ Koalisi Nasional Penghapusan Eksploitasi Seksual Komersial Anak, 2008, Eksploitasi Seksual Komersial Anak di Indonesia, Medan, Restu Printing Indonesia, hal.57
} 
mereka diberikan perlindungan oleh negara sebagai wujud Pancasila dan Undang-Undang Dasar 1945.

Tindak pidana perdagangan anak oleh ODCCP (Office for Drug Control and Crime Prevention) didefinisikan sebagai perekrutan, pemindahan, pengiriman, penempatan, atau penampungan anakanak di bawah umur dengan tujuan eksploitasi dengan penggunaan kekerasan, ancaman, ataupun tindak pemaksaan, penculikan, penipuan, penyalahgunaan wewenang maupun posisi-posisi tertentu. ${ }^{8}$

Perlindungan korban yang menjadikan anak selaku korban menurut Arif Gosita diartikan sebagai suatu usaha yang mengadakan kondisi yang melindungi anak dapat melaksanakan hak dan kewajibannya. ${ }^{9}$ Kasus Eksploitasi Seksual Komersial Anak di kecamatan Wonosari kabupaten Gunung Kidul terungkap dari hasil penelitian yang dilakukan ECPAT Indonesia bersama Kementerian Pemberdayaan Perempuan dan Anak (KPPPA) di tempat wilayah destinasi wisata prioritas bahwa masih ditemukan eksploitasi seksual anak. ${ }^{10}$ Secara spesifik mengenai pemberian perlindungan hukum kepada anak selaku korban tindak kejahatan mengartikan perlindungan kepada anak ialah segala bentuk usaha yang telah atau akan dilakukan untuk menciptakan kondisi agar setiap anak dapat melaksanakan hak serta kewajibannya demi perkembangan dan pertumbuhan anak secara wajar baik fisik, mental dan sosial. ${ }^{11}$ Perlindungan hukum terhadap korban dapat mencakup bentuk perlindungan abstrak atau perlindungan tidak secara langsung maupun perlindungan konkret atau perlindungan yang diberikan secara langsung. Dikatakan demikian karena tindak pidana menurut hukum positif tidak dilihat sebagai perbuatan menyerang atau melanggar kepentingan hukum seseorang (korban) secara pribadi dan konkret, tetapi hanya sebagai pelanggaran norma atau tertib hukum in abstracto. Akibatnya perlindungan korban pun tidak secara langsung dan in concreto. ${ }^{12}$

Bentuk perlindungan yang diberikan oleh setiap lembaga masyarakat dalam upaya melindungi anak korban perdagangan anak terus berkembang dan semakin baik, namun masih perlu dikembangkan dan dikaji lebih dalam lagi demi mengantisipasi terjadinya tindak pidana perdagangan anak dikemudian hari. Banyaknya kerugian yang anak alami sebagai korban perdagangan anak untuk dieksploitasi seksual komersial serta telah ditemukannya korban perdagangan anak perempuan dengan tujuan untuk dieksploitasi komersial di Wonosari maka hal tersebut yang mendorong penulis untuk melakukan penelitian tentang "upaya perlindungan hukum terhadap anak selaku korban kejahatan asusila dalam perdagangan anak".

\section{Rumusan Masalah}

Rumusan masalah yang disusun dalampeneltian ini adalah apa upaya perlindungan hukum terhadap anak sebagai korban eksploitasi seksual komersial dalam tindak pidana perdagangan anak?

\section{Metode Penelitian}

Penelitian ini merupakan penelitian hukum normatif dengan metode pendekatan analitis (analytical approach). Data yang diambil bersumber dari bahan hukum sekunder melalui kajian pustaka. Data yang diperoleh dikumpulkan, diolah, dan dianalisis secara perspektif dengan menggunakan metode deduktif.

\section{Hasil Penelitian dan Analisis}

\footnotetext{
${ }^{8}$ Muhammad Hadziq Alfatih, 2017, "Kerjasama Indonesia dan UNICEF dalam Menangani Kasus Child Trafficking di Indonesia”, Jurnal UNDIP, Volume III No.3

${ }^{9}$ Arif Gosita, 1985, Masalah Korban Kejahatan, Jakarta, Akademika Pressindo, hlm.42

${ }^{10} \mathrm{Ika}, 2017$, Anak jadi Korban Eksploitasi Seksual di 4 Destinasi Wisata, https://www.jawapos.com/nasional/hukum-kriminal/20/11/2017/anak-jadi-korban-eksploitasi-seksual-di-4destinasi-wisata/.

${ }^{11}$ Maidin Gultom, 2014, Perlindungan Hukum Terhadap Anak Dalam Sistem Peradilan Anak di Indonesia, Bandung, PT.Refika Aditama,, hlm.83

12 J. Hattu, 2010, "Perlindungan Hukum Terhadap Korban Kejahatan Ekonomi di Bidang Perbankan", Jurnal UNPATTI, Volume XIV No.4, hlm.39.
} 
Anak sebagai korban kejahatan eksploitasi seksual komersial (ESKA) haruslah memperoleh perlindungan hukum sebagaimana yang telah ditegaskan dalam Pasal 76 huruf I Undang-Undang Nomor 35 Tahun 2014 tentang Perubahan Atas Undang-Undang Nomor 23 Tahun 2002 tentang Perlindungan Anak yang melarang, "Setiap orang dilarang menempatkan, membiarkan, melakukan, menyuruh melakukan, atau turut serta melakukan eksploitasi secara ekonomi dan/atau seksual terhadap anak".

Perlindungan terhadap anak yang menjadi korban diatur dalam Undang-Undang Nomor 35 Tahun 2014 tentang Perubahan Atas Undang-Undang Nomor 23 Tahun 2002 tentang Perlindungan Anak juga mengatur apabila terjadi pelanggaran seperti memperdagangkan atau mengeksploitasi anak tercantum dalam Pasal 88 yang menyebutkan, "Setiap orang yang melanggar ketentuan sebagaimana dimaksud dalam Pasal 76 huruf I, dipidana dengan pidana penjara paling lama 10 (sepuluh) tahun dan/atau denda paling banyak Rp.200.000.000,00 (dua ratus juta rupiah)."

Kasus eksploitasi seksual komersial anak yang terjadi di Indonesia semakin marak terjadi, tingkat kejahatannya pun dari kelas lingkungan domestik hingga kejahatan yang mencapai kelas antar batas negara atau internasional. Penemuan-penemuan serta pelaporan tindak kejahatan perdagangan anak dengan tujuan seksual komersial dari tahun ke tahun selalu dapat dijumpai, dari yang berskala besar hingga yang perorangan saja. Pendataan kasus tindak kejahatan eksploitasi secara seksual komersial terhadap anak yang terjadi di Indonesia selalu dilakukan untuk memantau penerapan hukum yang berlaku di Indonesia sudah tepat ataukah belum. Berikut ini merupakan data kasus anak sebagai korban kejahatan eksploitasi secara seksual komersial yang terjadi di Indonesia sejak tahun 2011 sampai 2018:

Tabel 1

Jumlah Kasus Eksploitasi Seksual Komersial Anak di Indonesia

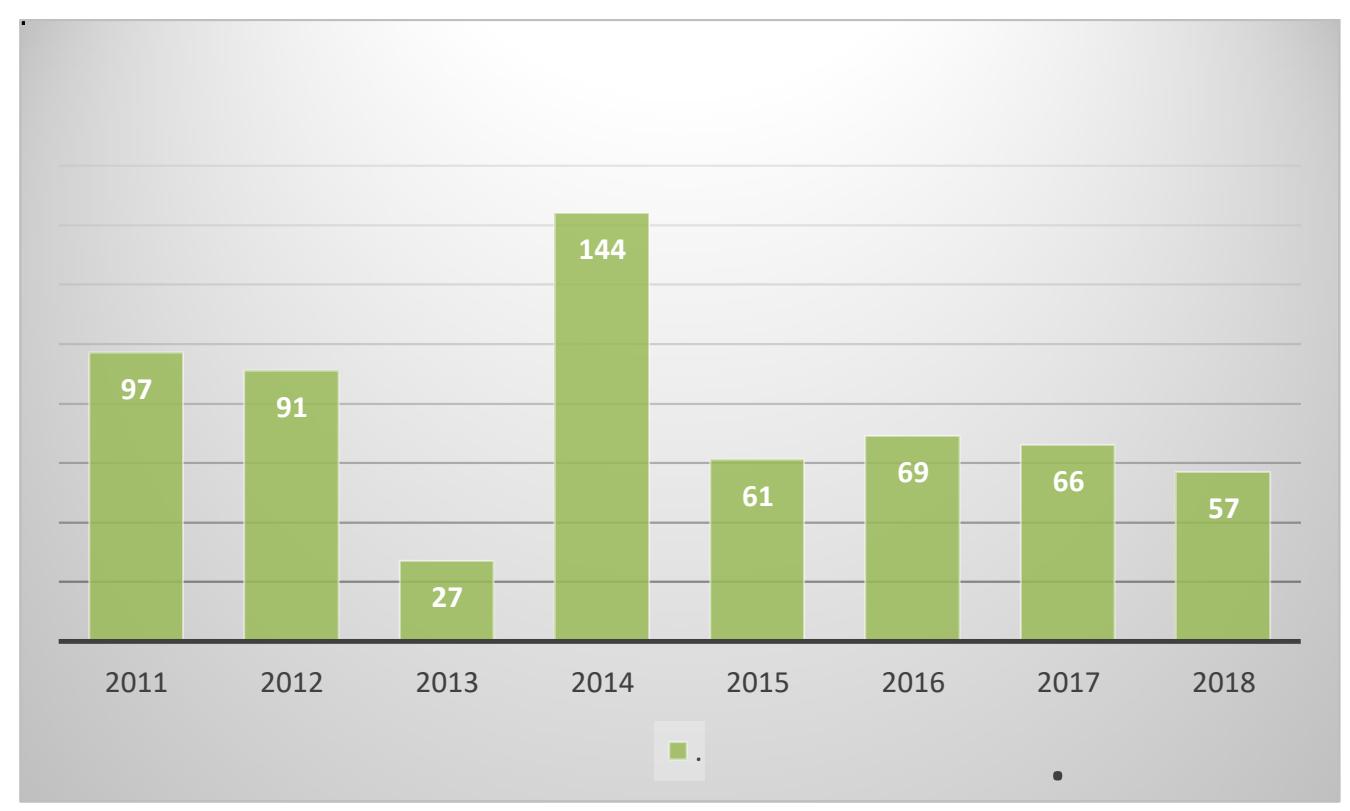

Sumber: Komisi Perlindungan Anak Indonesia

Berdasarkan Tabel 1 diatas, kasus eksploitasi seksual komersial anak di Indonesia yang terungkap dan ditangani pada tahun 2011-2018 sangat fluktuatif per tahunnya, diketahui pada tahun tahun 2014 terjadi peningkatan kasus hingga 144 kasus dalam satu tahun, dan pada tahun 2015 jumlah kasus mengalami penurunan hingga berjumlah 61 kasus dalam satu tahun dibanding dengan tahun sebelumnya. Total kasus eksploitasi seksual komersial anak dari tahun 2011-2018 mencapai 612 total kasus. Kasus merupakan hasil pelaporan langsung dari masyarakat/saksi kepada lembaga-lembaga perlindungan anak maupun ke kantor Kepolisian maupun hasil kinerja Kepolisian bersama awak media dalam menyelidiki adanya kasus ESKA. Kepolisian dan lembaga-lembaga 
perlindungan anak dapat membantu dalam mengungkap adanya tindak pidana perdagangan anak dengan tujuan eksploitasi seksual komersial anak dengan adanya kerja sama antar masyarakat.

Perlindungan yang diberikan terhadap anak yang menjadi korban ESKA mencakup perlindungan secara langsung (Concreto) maupun perlindungan secara tidak langsung (Abstracto). Bentuk perlindungan langsung yang diberikan kepada korban seperti pemberian yang bersifat materiil (kompensasi) seperti biaya pengobatan dan yang non-materiil seperti perlindungan dan menciptakan rasa aman terhadap anak melalui pendampingan korban. Bentuk perlindungan yang tidak langsung berupa penerapan norma-norma serta peraturan yang ditegakkan demi terciptanya perlindungan anak selaku korban tindak kejahatan.

KPAI Yogyakarta bersama lembaga perlindungan korban anak yang lainnya memberikan bentuk perlindungan yang dapat secara langsung (Concreto) anak selaku korban dapat rasakan seperti:

1. Memberikan bantuan untuk dapat memenuhi hak-hak anak sebagai korban eksploitasi seksual komersial anak sebagaimana yang telah tercantum dalam Undang-Undang Perlindungan Anak;

2. Melindungi dan mendampingi anak yang menjadi korban eksploitasi seksual komersial anak selama menjalankan proses hukum, dari pelaporan kasus pidana hingga setelah memperoleh putusan dari peradilan;

3. Memberikan pendampingan rehabilitasi secara psikologis kepada anak yang menjadi korban agar dapat pulih dan kembali menjadi anak sebagaimana semestinya.

Pemberian perlindungan secara tidak langsung (Abstracto) berupa penerapan peraturan hukum dan norma-norma serta pemberian perlindungan secara langsung (Concreto) berupa kompensasi merupakan bentuk perlindungan secara hukum yang tercantum dalam Pasal 6 ayat (1) dan Pasal 7 ayat (2) dan ayat (3) Undang-Undang Nomor 31 Tahun 2014 tentang Perubahan Atas Undang-Undang Nomor 13 Tahun 2006 tentang Perlindungan Saksi dan Korban, penjelasan Pasal 6 ayat (1) berbunyi:

"korban pelanggaran hak asasi manusia yang berat, Korban tindak pidana terorisme, Korban tindak pidana perdagangan orang, Korban tindak Pidana penyiksaan, Korban tindak pidana kekerasan seksual, dan Korban penganiayaan berat, selain berhak sebagaimana dimaksud dalam Pasal 5, juga berhak mendapatkan:

a. Bantuan medis; dan

b. Bantuan rehabilitasi psikososial dan psikologis."

Dan Pasal 7 ayat (2) dan ayat (3) berbunyi:

"Kompensasi bagi Korban pelanggaran hak asasi manusia yang berat diajukan oleh Korban, Keluarga, atau kuasanya kepada Pengadilan Hak Asasi Manusia melalui LPSK."

"Pelaksanaan pembayaran Kompensasi sebagaimana dimaksud pada ayat (2) diberikan oleh LPSK berdasarkan putusan pengadilan yang telah memperoleh kekuatan hukum tetap."

Terkait restitusi, anak yang menjadi korban kejahatan dalam hal ini kesusilaan, anak memiliki hak untuk memperoleh restitusi yang diatur dalam Pasal 71D UUPA dan itu merupakan tanggung jawab pelaku kejahatan.

\section{Kasus Posisi I}

Tindak pidana perdagangan anak dengan menempatkan, membiarkan, melakukan, menyuruh melakukan atau turut serta melakukan eksploitasi secara ekonomi dan/atau seksual terhadap anak yang terjadi di wilayah hukum Pengadilan Negeri Bengkulu. Perkara diputus di Pengadilan Negeri Bengkulu dengan Nomor Perkara 60/Pid.Sus/2018/PN.Bgl.

Terdakwa TITIN WARTINI binti (alm) JUMHADI lahir di Majalengka pada tanggal 3 Maret 1965 dengan jenis kelamin perempuan, bertempat tinggal di Kelurahan Sumber Jaya Kampung 
Melayu Kota Bengkulu. Beragama Islam dan pekerjaan yaitu pemiliki Cafe Romanza di Lokalisasi Pulau Baai, Kelurahan Sumber Jaya Kecamatan Kampung Melayu Kota Bengkulu.

\section{a. Kronologi Kasus}

Pada hari Rabu, tanggal 08 November 2017 sekira pukul 08.00 WIB. DONI membawa saksi korban UD dan saksi korban YA ke Cafe Romanza di Lokalisasi Pulau Baai milik Terdakwa, lalu DONI mengatakan kepada Terdakwa bahwa ke dua saksi korban tersebut bisa dipekerjakan untuk melayani para tamu untuk berhubungan seks dan menemani tamu untuk minum bir, Terdakwa menerima saksi korban UD dan saksi korban YA untuk bekerja di Cafenya dengan memberikan uang sebesar Rp.500.000 (lima ratus ribu rupiah) kepada DONI, setelah menerima uang DONI pergi meninggalkan Cafe Romanza.

Selanjutnya, saksi korban UD dan saksi korban YA selama tinggal di Cafe Romanza, bekerja melayani tamu di Cafe milik Terdakwa. Pekerjaan melayani tamu meliputi, menemani tamu untuk minum-minum, karaoke dan melayani tamu berhubungan badan (berhubungan sex).

Pada hari minggu tanggal 12 November 2017 sekitar pukul 00.00 Wib. Saksi Izef Kantona mendapat informasi dari anak saksi korban UD bahwa sekarang bekerja di Cafe Romanza di Lokalisasi Pulau Baai, saksi Izef Kantona memberi tahu saksi Tinto (kakak kandung dari anak UD), keesokan harinya, saksi Izef, saksi Tinto dan saksi Anton pergi menjemput saksi korban UD dan saksi korban YA di Cafe Romanza, kemudian pergi melapor atas kejadian tersebut ke Mapolda Bengkulu.

\section{b. Pertimbangan Hakim dalam Penjatuhan Putusan}

Pertimbangan hakim dalam menjatuhkan putusan sanksi pidana demi memberikan perlindungan hukum terhadap anak selaku korban dalam perkara Nomor 60/Pid.Sus/2018/PN.Bgl. yakni dengan memberatkan pemberian putusan berlandaskan bahwa perbuatan terdakwa telah merusak masa depan saksi korban serta telah menimbulkan trauma yang mendalam bagi saksi korban.

\section{c. Putusan}

Memperhatikan, Pasal 88 jo Pasal 76 I Undang-Undang Nomor 35 Tahun 2014 tentang Perubahan Atas Undang-Undang Nomor 23 Tahun 2002 tentang Perlindungan Anak, Undang-Undang Nomor 8 Tahun 1981 KUHAP seta peraturan-peraturan hukum lain yang bersangkutan dengan perkara ini:

1) Menyatakan terdakwa TITIN WARTINI Binti (Alm) JUMHADI telah terbukti secara sah dan meyakinkan bersalah melakukan tindak pidana "dengan sengaja dan melawan hukum melakukan eksploitasi secara ekonomi dan/atau seksual terhadap anak";

2) Menjatuhkan pidana terhadap terdakwa TITIN WARTINI Binti (Alim) JUMHADI tersebut oleh karena itu dengan pidana penjara selama: 3 (tiga) tahun dan 6 (enam) bulan dan denda sebesar Rp.50.000.000,- (lima puluh juta rupiah), apabila tidak dibayar maka diganti dengan pidana kurungan selama: 2 (dua) bulan.

\section{d. Analisis Kasus}

Seperti yang telah terpapar di atas, terdakwa dalam perkara ini telah melakukan tindak pidana eksploitasi secara seksual kepada anak karena telah melanggar Pasal 88 jo Pasal 76I Undang-Undang RI No.35 Tahun 2014 tentang Perubahan Atas Undang-Undang No.23 Tahun 2002 tentang Perlindungan Anak yang menyatakan bahwa "Setiap orang yang melanggar ketentuan sebagaimana dimaksud dalam Pasal 76I, dipidana dengan pidana penjara paling lama 10(sepuluh)tahun dan/atau denda paling banyak Rp.200.000.000,00 (dua ratus juta rupiah)".

Majelis hakim dalam putusannya tidak menerapkan secara penuh ketentuan pidana pada Pasal 88 UUPA karena tidak memaksimalkan pemberian sanksi pidana dalam putusannya sesuai dengan ketentuan Pasal 88 UUPA tersebut yang menjelaskan bahwa 
dapat diberikan sanksi pidana hingga maksimal 10 (sepuluh) tahun dan denda paling banyak Rp.200.000.000,- (dua ratus juta rupiah).

Terhadap pemberian perlindungan kepada korban yang mana dalam perkara ini adalah anak, pelaksanaan persidangan menjadi proses awal pelaksanaan perlindungan kepada korban anak, dan dalam pelaksanaannya korban dapat memperoleh restitusi atau kompensasi serta rehabilitasi. Pemberian perlindungan rehabilitasi berupa pemeriksaan mendik dan pendampingan psikologis dalam perkara ini telah terlaksanakan, terbukti dengan anak yang sudah membaik dan sudah bersekolah kembali.

Bentuk perlindungan bagi korban anak dalam kasus ini tidak memperoleh restitusi dari pihak terdakwa, semestinya berdasarkan pada Pasal 71D UUPA korban memiliki hak untuk memperoleh restitusi dengan melakukan permohonan restitusi kepada LPSK yang dijelaskan dalam Pasal 7A UU Perlindungan Saksi dan Korban.

\section{Kasus Posisi II}

Tindak pidana perdagangan anak dengan menempatkan, membiarkan, melakukan, menyuruh melakukan atau turut serta melakukan eksploitasi secara ekonomi dan/atau seksual terhadap anak yang terjadi di wilayah hukum Pengadilan Negeri Palopo. Perkara diputus di Pengadilan Negeri Palopo dengan Nomor Perkara 5/Pid.Sus-Anak/2018/PN.Plp.

Terdakwa anak lahir di Palopo pada tanggal 5 Mei 2001 dengan jenis kelamin perempuan, bertempat tinggal di Kelurahan Benteng, Kecamatan Wara Timur, Kota Palopo. Beragama Islam dan pekerjaan ibu rumah tangga.

\section{a. Kronologi Kasus}

Pada hari Rabu, tanggal 29 Desember 2017, IA mengajak Anak Korban pergi ke Wisma Sentosa untuk mencari tamu laki-laki. Ketika sampai di depan Wisma Sentosa, IA meminta Anak Korban untuk menunggu di motor dan IA masuk ke dalam Wisma Sentosa, tidak lama kemudian IA keluar dari dalam Wisma bersama dengan laki-laki yang tidak dikenal dan mendekati Anak Korban dan mengatakan "inimi Om, kita sukakah?" sambil menunjuk Anak Korban, kemudian IA saling tawar menawar sehingga terjadi kesepakatan Rp.300.000,- (tiga ratus ribu rupiah) selanjutnya IA menyuruh Anak Korban untuk mengikuti laki-laki yang tidak dikenal tersebut ke dalam kamar di Wisma Sentosa. Sewaktu di dalam kamar Anak Korban disetubuhi oleh laki-laki yang tidak dikenal kemudian mendapatkan uang sesuai kesepakatan yaitu Rp.300.000,- (tiga ratus ribu rupiah) kemudian Anak Korban memberikan uang tersebut kepada IA.

Sekitar tanggal 31 Desember 2017, Anak Korban dibawa oleh IA ke rumah Anak Terdakwa MSB dan mengatakan kepada Anak Terdakwa "anak Ayam ini" sambil menunjuk ke arah Anak Korban. Anak Terdakwa membawa Anak Korban menuju Wisma Pelangi di Jl. Benteng Raya karena banyak tamu, sesampainya di Wisma Pelangi, Anak Terdakwa menyuruh Anak Korban untuk menunggu di motor sementara itu Anak Terdakwa masuk ke dalam wisma untuk mencari tamu laki-laki. tidak lama kemudian, Anak Terdakwa keluar dari dalam wisma bersama dengan laki-laki yang tidak dikenal dan mengatakan "mau jaki tawwa om", lalu terjadi tawar menawar sehingga terjadi kesepakatan Rp.300.00,- (tiga ratus ribu rupiah), setelah itu Anak Korban masuk ke dalam wisma bersama dengan laki-laki yang tidak dikenal, lalu di dalam kamar Anak Korban disetubuhi oleh laki-laki yang tidak di kenal itu, kemudian setelah selesai disetubuhi Anak Korban diberikan uang sebesar Rp.300.000,(tiga ratus ribu rupiah) dan uang tersebut diserahkan Anak Korban kepada Anak Tersangka. Anak Korban mendapat uang sebesar Rp.200.000,- (dua ratus ribu rupiah) setiap kali melayani laki-laki yang tidak dikenal dan Anak Terdakwa mendapat keuntungan sebesar Rp.50.000,- (lima puluh ribu rupiah.

\section{b. Pertimbangan Hakim dalam Penjatuhan Putusan}

Pertimbangan hakim dalam menjatuhkan putusan sanksi pidana demi memberikan perlindungan hukum terhadap anak selaku korban dalam perkara Nomor 5/Pid.SusAnak/2018/PN.Plp. yakni dengan memberikan pertimbangan, bahwa disisi lain pengadilan 
berpendapat walaupun anak pelaku masih berusia anak-anak akan tetapi terhadap perbuatan yang dilakukan anak haruslah di jatuhi pidana dengan memperhatikan segala aspek, baik itu yuridis, sosiologis maupun aspek psikologis bagi anak maupun korban.

c. Putusan

Memperhatikan, Pasal 88 jo Pasal 76 I Undang-Undang Nomor 17 Tahun 2016 tentang Penetapan Peraturan Pemerintah Pengganti Undang-Undang Nomor 1 Tahun 2016 tentang Perubahan Kedua Atas Undang-Undang Nomor 23 Tahun 2002 tentang Perlindungan Anak menjadi Undang-Undang Nomor 11 Tahun 2012 tentang Sistem Peradilan Pidana Anak serta peraturan perundang-undangan lain yang bersangkutan:

1) Menyatakan Anak Pelaku MSB tersebut diatas, terbukti secara sah dan meyakinkan bersalah melakukan tindak pidana "Melakukan Eksploitasi Secara Seksual Terhadap Anak" sebagaimana dalam dakwaan alternatif pertama;

2) Menjatuhkan pidana kepada Para Anak Pelaku oleh karena itu dengan pidana penjara selama 1 (satu) tahun 4 (empat) bulan.

\section{d. Analisis Kasus}

Seperti yang telah terpapar di atas, terdakwa dalam perkara kedua ini merupakan anak yang melakukan tindak kejahatan. Dengan banyak pertimbangan yang dilakukan oleh jaksa penuntut umum terhadap anak, maka jaksa menuntut dalam surat dakwaan untuk memberian sanksi pidana selama 2 (dua) tahun dan 6 (enam) bulan kepada anak selaku terdakwa.

Majelis hakim dalam perkara ini memberikan keringanan dengan banyaknya pertimbangan terhadap terdakwa anak, karena terdakwa masih tergolong anak dan masih bisa memperoleh pengarahan serta ada kesempatan untuk menjadi lebih baik, majelis hakim memberikan sanksi pidana selama 1 (satu) tahun 4 (empat) bulan kepada terdakwa anak.

Penulis berpendapat berdasarkan kedua kasus perkara yang telah diselesaikan dan mendapat putusan di persidangan peradilan ini. Pemberian informasi mengenai hak-hak atau bentuk perlindungan korban dalam perkara ini ialah anak, yang mana telah tercantum penjelasannya pada Pasal 64 UUPA. Pemberian ganti rugi kepada korban dari palaku di Indonesia belum merupakan suatu hal yang wajib dilakukan, terbukti dari setiap peradilan apabila restitusi tidak diminta melalui permohonan, maka korban tidak akan mendapatkan ganti rugi biaya akibat perbuatan pelaku terhadap korban, terutama dalam hal dan perkara ini adalah anak.

Peraturan perundang-undangan dalam hal ini kejahatan berbentuk eksploitasi secara seksual komersial yang tertuju kepada anak harus dilaksanakan semaksimal mungkin, tidak hanya memberikan sanksi hukuman terhadap para pelaku kejahatan agar menciptakan efek jera dikemudian hari dan tidak bermunculan

\section{Kasus Posisi III}

Tindak pidana perdagangan anak dengan menempatkan, membiarkan, melakukan, menyuruh melakukan atau turut serta melakukan eksploitasi secara ekonomi dan/atau seksual terhadap anak yang terjadi di wilayah kecamatan Wonosari kabupaten Gunung Kidul, kasus ini tidak memiliki Putusan Pengadilan dikarenakan kasus yang terjadi tidak dibawa melalui jalur hukum oleh pihak korban dan hanya diselesaikan melalui jalur kekeluargaan. Terdakwa merupakan kepala dukuh setempat yang memperdagangkan anak untuk memperoleh keuntungan dari hasil perdagangan tersebut.

\section{a. Kronologis Kasus}

Pada kasus ESKA yang terjadi di kecamatan Wonosari kabupaten Gunung Kidul, ibu Indri selaku perwakilan KPAI Yogyakarta bersama lembaga perlindungan anak yang terjun kelapangan mendapati bahwa pelaku merupakan kepala dukuh tempat anak tersebut tinggal. KPAI yang diwakili Ibu Indri hanya bertindak sebagai pihak ke 3(tiga) atau mediator 
dari kasus yang terjadi dan menanyakan kepada para pihak apakah ingin dilanjutkan melalui jalur hukum atau persidangan apa tidak, pihak dari keluarga korban tidak mau membawa kasus tersebut melalui jalur hukum dengan alasan pekewuh (sungkan) karena beliau merupakan tokoh masyarakat bagi masyarakat setempat. Dengan jawaban dari pihak keluarga seperti itu, KPAI sebagai pihak ketiga dan lembaga yang membela hak anak, KPAI hanya bisa memberikan pertolongan atau perlindungan dengan pengawasan serta pemberian bimbingan konseling bersama psikolog sesuai dengan tata tindakan perlindungan agar anak tidak mengalami depresi yang berkelanjutan.

\section{b. Analisis Kasus}

Analisis terhadap kasus ESKA yang terjadi di Wonosari, hasil temuan KPAI Yogyakarta menurut penulis telah menunjukkan gugurnya hukum yang tercantum dalam Pasal 88 jo Pasal 76 huruf I UUPA yang melarang, "Setiap orang dilarang menempatkan, membiarkan, melakukan, menyuruh melakukan, atau turut serta melakukan eksploitasi secara ekonomi dan/atau seksual terhadap anak". Serta menghilangkan beberapa hak dari korban yang tercantum dalam pada Pasal 64 UUPA.

Gugurnya hukum dalam kasus eksploitasi seksual komersial anak di Wonosari Gunung Kidul yang seyogyanya dimiliki oleh anak yang menjadi korban eksploitasi seksual komersial, mengakibatkan anak tidak memperoleh restitusi dan/atau kompensasi yang merupakan 2 (dua) bentuk perlindungan hukum terhadap korban yang diatur pemberiannya oleh negara dalam Undang-Undang Perlindungan Saksi dan Korban.

Pemberian restitusi dan/atau kompensasi merupakan upaya perlindungan hukum yang tertuang dengan jelas dalam aturan perundang-undangan Indonesia. Namun dalam implementasi hukum kasus ESKA di kecamatan Wonosari kabupaten Gunung Kidul, anak selaku korban tidak dapat memperoleh restitusi dan/atau kompensasi, dikarenakan dalam mediasi kasus tersebut berujung jawaban untuk tidak melalui jalur hukum dan persidangan, sehingga korban anak tidak dapat memperoleh keadilannya.

Upaya perlindungan dan bantuan hukum yang telah diusahakan lembaga KPAI Yogyakarta untuk korban anak ESKA di kecamatan Wonosari kabupaten Gunung Kidul Yogyakarta hanyalah terbatas, dan tidak dapat berlaku secara maksimal kepada anak yang menjadi korban. Implementasi perlindungan hukum terhadap anak yang dilakukan oleh pemerintah seharusnya lebih maksimal daripada yang dilakukan oleh lembaga selain pemerintah (non government organization) seperti KPAI dan Rifka Annisa. Namun bentuk serta upaya perlindungan hukum yang dilakukan pemerintah berdasarkan peraturan yang ada dinilai masih sangat kurang hasil pencapaiannya.

\section{Simpulan dan Saran}

\section{Simpulan}

Upaya perlindungan hukum terhadap korban kasus eksploitasi seksual komersial anak dapat dilakukan secara langsung (concreto) dengan cara memberikan bantuan hukum kepada anak untuk dapat terpenuhinya hak-hak sebagai korban eksploitasi seksual komersial, memberikan perlindungan serta pendampingan terhadap anak sebagai korban eksploitasi seksual komersial selama menjalani proses hukum dan mengupayakan perolehan restitusi dan/atau kompensasi terhadap anak dengan pengajuan melalui Lembaga Perlindungan Saksi dan Korban. Perlindungan hukum lainnya dapat dilakukan secara tidak langsung (abstracto) melalui penerapan norma-norma dan peraturan hukum terhadap anak sesuai peraturan perundang-undangan.

\section{Saran}

Setelah memberikan kesimpulan, Penulis ingin mengajukan saran-saran sebagai berikut:

1. Masyarakat serta anak perlu untuk mendapat informasi mengenai dampak serta bahayanya tindak pidana eksploitasi seksual komersial terhadap anak agar dapat dilakukannya pencegahan sejak dini. Apabila dilingkungan terjadi sebuah kejahatan terhadap anak, 
masyarakat diharapkan mau untuk melaporkan dan membantu untuk memberikan perlindungan dan membela hak-hak yang dimiliki oleh anak.

2. Pemerintah diharapkan dapat membangun ruang perlindungan terhadap anak hingga ke setiap daerah untuk mempermudah diperolehnya informasi serta tempat berlindung bagi anak-anak yang menjadi korban.

\section{DAFTAR PUSTAKA}

\section{Buku}

Ahmad Sofian, 2008, Eksploitasi Seksual Komersial Anak di Indonesia, Medan, Koalisi Nasional Penghapusan Eksploitasi Seksual Komersial Anak

Arif Gosita, 1985, Masalah Korban Kejahatan, Jakarta, Akademika Pressindo

Kementerian Ketenagakerjaan RI, 2014, Peta Jalan (Roadmap) Menuju Indonesia Bebas Pekerja Anak Tahun 2022, Jakarta,

Koalisi Nasional Penghapusan Eksploitasi Seksual Komersial Anak, 2008, Eksploitasi Seksual Komersial Anak di Indonesia, Medan, Restu Printing Indonesia

Maidin Gultom, 2014, Perlindungan Hukum Terhadap Anak Dalam Sistem Peradilan Anak di Indonesia, Bandung, PT.Refika Aditama

Mohammad Taufik Makaro, 2013, Hukum Perlindungan Anak dan Penghapusan Kekerasan Dalam Rumah Tangga,Jakarta, Rineka Cipta.

\section{Jurnal}

J. Hattu, 2010, "Perlindungan Hukum Terhadap Korban Kejahatan Ekonomi di Bidang Perbankan", Jurnal UNPATTI, Volume XIV No.4

Muhammad Hadziq Alfatih, 2017, "Kerjasama Indonesia dan UNICEF dalam Menangani Kasus Child Trafficking di Indonesia”, Jurnal UNDIP, Volume III No.3

\section{Internet}

Ika, 2017, Anak jadi Korban Eksploitasi Seksual di 4 Destinasi Wisata, https://www.jawapos.com/nasional/hukum-kriminal/20/11/2017/anak-jadi-korban-eksploitasiseksual-di-4-destinasi-wisata/

Iman Rahdana, 2018, Catatan Tahun 2017: 404 Anak Menjadi Korban ESKA, https://ecpatindonesia.org/berita/catatan-ecpat-indonesia-tahun-2017-404-anak-menjadikorban-eska/, diakses 15 Januari 2018.

Marsaha Habib, Prostitusi Anak: Jangan Salah Fokus, 18 Oktober 2016, https://medium.com/@puskapa/prostitusi-anak-jangan-salah-fokus-16393be09e8f

Muh Syaifullah, 2016, Pelacuran Anak Marak, Pemerintah Didesak Bertindak, https://nasional.tempo.co/read/791363/pelacuran-anak-marak-pemerintah-didesakbertindak/full\&view $=0 \mathrm{k}$ 